Jurnal Keperawatan Silampari

Volume 5, Nomor 1, Desember 2021

e-ISSN: 2581-1975

p-ISSN: 2597-7482

DOI: https://doi.org/10.31539/jks.v5i1.2894

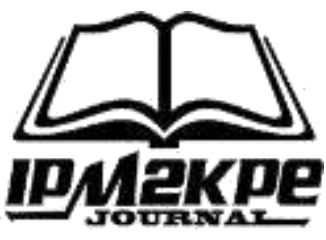

\title{
MOTIVASI DAN SUPERVISI BERHUBUNGAN DENGAN KINERJA INFECTION PREVENTION AND CONTROL LINK NURSE (IPCLN) DALAM MENERAPKAN PENCEGAHAN DAN PENGENDALIAN INFEKSI
}

\author{
Afriani $^{1}$, Mudatsir ${ }^{2}$, Suryane Sulistiana Susanti ${ }^{3}$ \\ Universitas Syiah Kuala ${ }^{1,2,3}$ \\ afriani78@mhs.unsyiah.ac.id ${ }^{1}$
}

\begin{abstract}
ABSTRAK
Penelitian ini bertujuan untuk mengetahui hubungan antara motivasi dan supervisi dengan kinerja perawat dalam melaksanakan pencegahan dan pengendalian infeksi pada rumah sakit di Provinsi Aceh. Metode penelitian yang digunakan adalah penelitian cross sectional study. Hasil penelitian menunjukkan bahwa motivasi dan supervisi berhubungan signifikan dengan kinerja Perawat Pencegahan dan Pengendalian Infeksi di RSUD Kota Banda Aceh dan Kab. Aceh Besar (P-value < 0,05). Simpulan, variabel motivasi yaitu kebutuhan untuk berprestasi merupakan prediktor yang paling dominan berhubungan dengan kinerja Perawat Pencegahan dan Pengendalian Infeksi di RSUD Kota Banda Aceh dan Kab. Aceh Besar.
\end{abstract}

Kata Kunci: IPCLN, Kinerja, Motivasi, Perawat, Supervisi

\begin{abstract}
This study aims to determine the relationship between motivation and supervision with the performance of nurses in implementing infection prevention and control in hospitals in Aceh Province. The research method used was a cross-sectional study. The results showed that motivation and supervision were significantly related to the performance of Infection Prevention and Control Nurses in Banda Aceh City Hospital and Kab. Aceh Besar (P-value < 0.05). In conclusion, the motivation variable, namely the need for achievement, is the most dominant predictor associated with the performance of Infection Prevention and Control Nurses at the Banda Aceh City Hospital and Kab. Aceh Besar.
\end{abstract}

Keywords: IPCLN, Performance, Motivation, Nurse, Supervision

\section{PENDAHULUAN}

Hospital Acquired Infections (HAI) merupakan salah satu masalah keamanan bagi penyedia layanan kesehatan dan pasien. Beberapa data hasil penelitian menunjukkan bahwa prevalensi HAI pada negara maju bervariasi antara 3,5\% sampai $12 \%$. Prevalensi HAI di negara-negara Eropa rata-rata sebesar 7,1\%. Andersen (2019) menyatakan di Eropa diperkirakan bahwa 4.131.000 pasien mengalami sekitar 4.544.100 episode HAI setiap tahun. Perkiraan tingkat kejadian HAI di Amerika Serikat sebesar 4,5\% pada tahun 2019, atau sama dengan 9,3 infeksi per 1.000 pasien/hari dan sebanyak 1,7 juta pasien terkena dampak. Proporsi pasien yang terinfeksi di unit perawatan intensif 
sebesar 51\% dan sebagian besar diantaranya terjadi di rumah sakit. Sekitar $30 \%$ pasien di ICU setidaknya mengalami satu episode HAI. Semakin lama pasien tinggal di ICU, maka semakin berisiko mereka tertular infeksi. Frekuensi infeksi yang tinggi dikaitkan dengan penggunaan perangkat invasif, khususnya saluran sentral, kateter urine dan ventilator.

World Health Organization mencatat bahwa prevalensi HAI di negara-negara berpenghasilan rendah dan menengah tahun 2019 berkisar antara 5,7\% dan 19,1\%. Proporsi pasien HAI di ICU berkisar antara 4,4\% hingga 88,9\% dengan frekuensi keseluruhan infeksi mencapai 42,7 episode per 1000 pasien per-hari. Angka ini hampir tiga kali lebih tinggi dari pada di negara-negara berpenghasilan tinggi. Selain itu, di beberapa negara berkembang frekuensi infeksi yang terkait dengan penggunaan saluran sentral dan ventilator serta perangkat invasif lainnya dapat mencapai 19 kali lebih tinggi dari pada yang dilaporkan dari Jerman dan Amerika Serikat (Voidazan et al., 2020).

Bayi baru lahir juga berisiko lebih tinggi, dengan tingkat infeksi di negara-negara berkembang 3-20 kali lebih tinggi daripada di negara-negara berpenghasilan tinggi. Andersen (Andersen, 2019) mencatat, diantara bayi yang lahir di rumah sakit di negara berkembang, HAI sekitar 4\% hingga 56\% dari semua penyebab kematian pada periode neonatal dan $75 \%$ di Asia Tenggara dan Afrika. Infeksi lokasi pembedahan merupakan infeksi utama pada populasi pasien umum di negara-negara dengan sumber daya terbatas dan mempengaruhi hingga dua pertiga dari pasien yang menjalani pembedahan dan dengan frekuensi hingga sembilan kali lebih tinggi dari pada di negara maju (Andersen, 2019).

Sebagai salah satu negara berkembang, Indonesia juga tidak luput dari kejadian HAI. Kasumayanti (2017) dalam penelitiannya menyatakan bahwa pada tahun 2010 terjadi kejadian infeksi nosokomial sebesar 6-16\% dengan rata- rata 9,8\%. Di NTT, salah satu Rumah Sakit yang menjadi rujukan utama mencatat adanya infeksi nosokomial yang terjadi pada tahun 2014 sebesar 0,17\%. Di Aceh, berdasarkan laporan tahun 2019 diketahui kejadian infeksi saluran kemih (ISK) sebesar 2,6 permil, infeksi aliran darah primer (IADP) sebanyak 0 permil, ventilator-associated pneumonia (VAP) 4,3 permil dan infeksi daerah operasi sebesar 1,1 persen (PPI, 2019).

Dalam konteks kasus HAI, Perawat memainkan peran penting dalam mencegah dan mengendalikan penularan infeksi melalui penerapan tindakan pencegahan standar dan pemeliharaan lingkungan perawatan kesehatan (Marbun, 2020; Romadhoni \& Widowati, 2017). WHO (2016) mengklasifikasikan beberapa peran staf perawat untuk pengendalian infeksi. Perawat di berbagai tingkatan, yaitu: administrator perawat senior, perawat perawatan lingkungan dan perawat yang bertanggungjawab atas pengendalian infeksi. Selain itu, komite kontrol perlu dibentuk untuk mengembangkan programmer pelatihan untuk anggota staf keperawatan; mengawasi pelaksanaan teknik untuk pencegahan infeksi (Storr et al., 2017).

Dalam konteks HAI, salah satu cara perawat untuk berperan dalam pengendalian infeksi di rumah sakit adalah dengan menjadi Infection Prevention and Control Link Nurse (IPCLN), yaitu perawat yang menjadi perantara atau link antara perawat di ruang rawat dengan tim pengendali infeksi rumah sakit (Niken, 2020). IPCLN memainkan peran penting dalam pencegahan dan pengendalian infeksi rumah sakit karena melakukan kontak langsung dengan pasien melalui prosedur invasif dan berpotensi untuk terkontaminasi, serta melakukan kesalahan pada peralatan, instrumen dan obatobatan pasien (Hutahaean \& Handiyani, 2018; Sapardi et al., 2018). 
Lebih lanjut, Salem (2019) dalam penelitiannya mengemukakan bahwa 60\% perawat memiliki pengetahuan yang baik dan $51,7 \%$ memiliki praktik yang buruk tentang tindakan pengendalian infeksi. Kemudian Fitriyah et al., (2018) juga menyatakan hal yang senda bahwa Infection Prevention and Control Nurse (IPCN) memainkan peran yang penting sebagai praktisi klinis, koordinator kegiatan, administrator dan pendidik. Namun peran IPCN belum optimal karena kurangnya dukungan dari manajemen rumah sakit, infrastruktur yang tidak memadai, pemantauan dan supervisi yang lemah dan kurangnya motivasi akibat tidak tersedianya imbalan dan hukuman yang sesuai.

Di Aceh, jumlah perawat yang menjadi IPCLN sampai dengan awal tahun 2020 pada 7 (tujuh) rumah sakit di Kota Banda Aceh adalah 131 orang. Sedangkan di RSUD Kab. Aceh Besar sebanyak 9 orang. Di salah satu rumah sakit di Kota Banda Aceh diketahui bahwa dari enam tugas perawat IPCLN hanya satu tugas yang dilaksanakan yaitu pelaporan angka kejadian HAI. Sedangkan kegiatan tugas lainnya seperti edukasi, monitoring kepatuhan terhadap protokol pencegahan infeksi dan lain-lain belum dilaksanakan. Beberapa penelitian terdahulu menyebutkan bahwa salah satu faktor penyebab kurang optimalnya pelaksanaan IPCLN berhubungan dengan supervisi dan motivasi kerja perawat (Asmara et al., 2019; Siahaan et al., 2019; Suwito et al., 2017). Penelitian ini masih jarang dilakukan, khususnya di tempat penelitian belum ada penelitian yang sama sebelumnya.

\section{METODE PENELITIAN}

Penelitian ini menggunakan pendekatan cross sectional study dengan jumlah populasi penelitian adalah 64 orang perawat IPCLN dan dipilih menggunakan teknik total sampling. Pengumpulan data penelitian ini dilakukan dari tanggal 14 Desember 2020 sampai dengan 14 Januari 2021 pada empat Rumah Sakit di Kota Banda Aceh dan satu Rumah Sakit di Kab. Aceh Besar. Instrumen penelitian menggunakan The Unified Motive Scales (UMS) yang diadopsi dari kajian Schönbrodt \& Gerstenberg pada tahun 2012 dan Manchester Clinical Supervision Scale 26 (MCSS 26) yang diadopsi dari Winstanley \& White. Kedua instrumen tersebut telah diterjemahkan ke dalam bahasa Indonesia dan telah diuji validitas dan reliabilitasnya terhadap 10 perawat IPCLN di RSUD Tgk. Chik Ditiro Sigli secara online menggunakan aplikasi google form dan dinyatakan valid dan reliabel. Data yang diperoleh dianalisis menggunakan statistik deskriptif, yaitu distribusi frekuensi untuk mengetahui persentase setiap katagori dari variabel penelitian, kemudian uji statistik non parametrik, yaitu Chi-Square Test dan uji Regresi Logistik dengan metode Stepwise.

\section{HASIL PENELITIAN}

Tabel. 1

Karakteristik Perawat IPCLN

pada Rumah Sakit $(\mathrm{N}=64)$

\begin{tabular}{ccc}
\hline Karakteristik & Frekuensi & Persentase \\
\hline Umur & & \\
\hline Dewasa Awal & 12 & 18.8 \\
Dewasa Pertengahan & 45 & 70.3 \\
Dewasa Akhir & 7 & 10.9 \\
\hline
\end{tabular}




\begin{tabular}{ccc}
\hline Jenis Kelamin & 3 & \\
Laki-Laki & 61 & 4.7 \\
Perempuan & & 95.3 \\
\hline Pendidikan Terakhir & 1 & 1.6 \\
\hline S2 Keperawatan & 18 & 28.1 \\
Ners & 9 & 14.1 \\
S1 Keperawatan & 5 & 7.8 \\
D.IV Keperawatan & 30 & 46.9 \\
D.III Keperawatan & 1 & 1.6 \\
\hline SPK & 64 & 100,0 \\
\hline Status Perkawinan & 63 & 98.4 \\
Kawin & 1 & 1.6 \\
Duda/Janda & 64 & 100,0 \\
\hline Status Kepegawaian & 54 & 84.4 \\
\hline PNS & 10 & 15.6 \\
Kontrak & & 92.2 \\
\hline Masa Kerja & 59 & 7.8 \\
\hline$\geq 5$ Tahun & 5 & \\
\hline < Tahun & &
\end{tabular}

Berdasarkan tabel 1 menunjukkan bahwa dari 64 orang perawat IPCLN pada Rumah Sakit di Kota Banda Aceh dan Kab. Aceh Besar, 45 orang $(70,3 \%)$ berumur dewasa pertengahan, 61 orang $(95,3 \%)$ perempuan, 30 orang $(46,9 \%)$ berpendidikan D.III Keperawatan, 63 orang $(98,4 \%)$ berstatus kawin, 54 orang $(84,4 \%)$ merupakan PNS dan 59 orang $(92,2 \%)$ dengan masa kerja $\geq 5$ tahun.

Tabel. 2

Motivasi Perawat IPCLN $(n=64)$

\begin{tabular}{ccc}
\hline Variabel & Frekuensi & Persentase \\
\hline Motivasi & & \\
\hline Tinggi & 26 & 40,6 \\
Rendah & 38 & 59,4 \\
\hline Kebutuhan untuk prestasi & & \\
\hline Tinggi & 28 & 43.8 \\
Rendah & 36 & 56.2 \\
\hline Kebutuhan akan kekuasaan & & \\
\hline Tinggi & 27 & 42.2 \\
Rendah & 37 & 57.8 \\
\hline Kebutuhan untuk berafiliasi & & 51.6 \\
\hline Tinggi & 33 & 48.4 \\
\hline Rendah & 31 &
\end{tabular}

Berdasarkan tabel 2 diketahui bahwa dari 64 orang perawat IPCLN pada Rumah Sakit di Kota Banda Aceh dan Kab. Aceh Besar, 38 orang $(59,4 \%)$ memiliki motivasi yang rendah. Selanjutnya hasil analisis motivasi berdasarkan kebutuhan diperoleh hasil bahwa dari 64 orang perawat IPCLN pada Rumah Sakit di Kota Banda Aceh dan Kab. 
Aceh Besar, 36 orang (56,2\%) memiliki kebutuhan untuk berprestasi yang rendah, 37 orang $(57,8 \%)$ memiliki kebutuhan akan kekuasaan yang rendah dan 33 orang $(51,6 \%)$ memiliki kebutuhan untuk berafiliasi yang tinggi.

Tabel. 3

Supervisi Keperawatan

bagi Perawat IPCLN r $(n=64)$

\begin{tabular}{ccc}
\hline Variabel & Frekuensi & Persentase \\
\hline Supervisi & & \\
\hline Efektif & 50 & 78.1 \\
Tidak Efektif & 14 & 21.9 \\
\hline Kinerja & & 35.9 \\
Baik & 23 & 64.1 \\
\hline Kurang & 41 &
\end{tabular}

Berdasarkan tabel 3 menunjukkan bahwa dari 64 orang perawat IPCLN pada Rumah Sakit di Kota Banda Aceh dan Kab. Aceh Besar, 50 orang $(78,1 \%)$ menyatakan pelaksanaan supervisi efektif. Kemudian dari 64 orang perawat IPCLN pada Rumah Sakit di Kota Banda Aceh dan Kab. Aceh Besar, 41 orang $(64,1 \%)$ memiliki kinerja yang kurang.

Tabel 4

Hubungan Motivasi dan Supervisi dengan Kinerja Perawat IPCLN $(n=64)$

\begin{tabular}{|c|c|c|c|c|}
\hline \multirow{2}{*}{ Variabel } & \multicolumn{3}{|c|}{ Kinerja Perawat IPCLN } & \multirow{2}{*}{ P-Value } \\
\hline & Baik & Kurang & Total & \\
\hline \multicolumn{5}{|l|}{ Motivasi } \\
\hline Tinggi & $17(65,4)$ & $9(34,6)$ & $26(100,0)$ & \multirow{2}{*}{0,000} \\
\hline Rendah & $6(15,8)$ & $32(84,2)$ & $38(100,0)$ & \\
\hline \multicolumn{5}{|c|}{ Kebutuhan Berprestasi } \\
\hline Tinggi & $20(71,4)$ & $8(28,6)$ & $28(100,0)$ & \multirow{2}{*}{0,000} \\
\hline Rendah & $3(8,3)$ & $33(91,7)$ & $36(100,0)$ & \\
\hline \multicolumn{5}{|c|}{ Kebutuhan Kekuasaan } \\
\hline Tinggi & $8(29,6)$ & $19(70,4)$ & $27(100,0)$ & \multirow{2}{*}{0,526} \\
\hline Rendah & $15(40,5)$ & $22(59,5)$ & $37(100,0)$ & \\
\hline \multicolumn{5}{|c|}{ Kebutuhan Afiliasi } \\
\hline Tinggi & $1(3,0)$ & $32(97,0)$ & $33(100,0)$ & \multirow{2}{*}{0,000} \\
\hline Rendah & $22(71,0)$ & $9(29,0)$ & $31(100,0)$ & \\
\hline \multicolumn{5}{|l|}{ Supervisi } \\
\hline Efektif & $21(45,7)$ & $25(54,3)$ & $46(100,0)$ & \multirow{2}{*}{0,021} \\
\hline Tidak Efektif & $2(11,1)$ & $16(88,9)$ & $18(100,0)$ & \\
\hline
\end{tabular}

Berdasarkan tabel 4 menunjukkan bahwa terdapat hubungan yang antara motivasi perawat dengan kinerja perawat IPCLN pada Rumah Sakit di Kota Banda Aceh dan Kab. Aceh Besar dengan p-value $=0,000$. Kemudian, dari masing-masing sub variabel motivasi, hasil uji menunjukkan bahwa kebutuhan berprestasi dan kebutuhan afiliasi memiliki hubungan dengan kinerja perawat IPCLN dengan $\mathrm{p}$-value $=0,000$. Sedangkan sub variabel kebutuhan kekuasaan tidak berhubungan dengan kinerja perawat IPCLN dengan $\mathrm{p}$-value $=0,526$. 
Motivasi dan supervisi perawat yang paling dominan berhubungan dengan kinerja perawat IPCLN pada Rumah Sakit di Kota Banda Aceh dan Kab. Aceh Besar dianalisis menggunakan uji Binary Logistic Regression dengan metode Stepwise. Uji ini untuk mengetahui kelayakan motivasi dan supervisi perawat untuk dimasukkan ke dalam model regresi logistik. Uji kelayakan model ini pada variabel motivasi dan supervisi dilakukan secara terpisah untuk masing-masing variabel. Kriteria variabel yang dapat dimasukkan ke dalam model regresi logistik adalah apabila nilai $\mathrm{p}$-value $<0,25$.

Tabel. 5

Hasil Analisis Step 1 Motivasi dan Supervisi sebagai Prediktor Kinerja Perawat IPCLN $(n=64)$

\begin{tabular}{lccccc}
\hline \multirow{2}{*}{ Prediktor } & \multirow{2}{*}{$\mathrm{B}$} & \multirow{2}{*}{ OR } & \multirow{2}{*}{ P-Value } & \multicolumn{2}{c}{$95 \%$ CI } \\
\cline { 5 - 6 } & & & & Lower & Upper \\
\hline Kebutuhan Berprestasi & 1,957 & 7,078 & 0,038 & 1,118 & 44,806 \\
Kebutuhan Berafiliasi & 3,406 & 0,033 & 0,003 & 0,004 & 0,313 \\
Supervisi & 0,308 & 1,361 & 0,790 & 0,142 & 13,056 \\
\hline
\end{tabular}

Berdasarkan tabel 5 menunjukkan bahwa kebutuhan berprestasi $(\mathrm{P}=0,038)$ dan kebutuhan untuk berafiliasi $(\mathrm{P}=0,003)$ memperoleh nilai signifikan $<0,05$ sehingga layak untuk masuk ke analisis step selanjutnya. Sedangkan supervisi $(\mathrm{P}=0,790)$ memperoleh nilai signifikan $>0,05$ sehingga tidak layak untuk dimasukkan ke dalam analisis step selanjutnya.

Tabel. 6

Hasil Analisis Step 2 Motivasi dan Supervisi

sebagai Prediktor Kinerja Perawat IPCLN $(n=64)$

\begin{tabular}{lccccc}
\hline \multicolumn{1}{c}{ Prediktor } & \multirow{2}{*}{$\mathrm{B}$} & OR & \multirow{2}{*}{ P-Value } & \multicolumn{2}{c}{$95 \%$ CI } \\
\cline { 5 - 6 } & & & & Lower & Upper \\
\hline Kebutuhan berprestasi & 2,062 & 7,858 & 0,017 & 1,451 & 42,553 \\
Kebutuhan berafiliasi & 3,433 & 0,032 & 0,003 & 0,003 & 0,303 \\
Constant & 1,965 & 7,134 & 0,083 & & \\
\hline
\end{tabular}

Berdasarkan tabel 6 menunjukkan bahwa kebutuhan berprestasi $(\mathrm{P}=0,017)$ dan kebutuhan untuk berafiliasi $(\mathrm{P}=0,003)$ memperoleh nilai signifikan $<0,05$ sehingga dapat dinyatakan bahwa kebutuhan berprestasi dan kebutuhan berafiliasi berhubungan secara signifikan dengan kinerja perawat IPCLN pada Rumah Sakit di Kota Banda Aceh dan Kab. Aceh Besar. Hasil pengujian juga menunjukkan bahwa kebutuhan untuk berprestasi merupakan prediktor yang paling dominan berhubungan dengan kinerja perawat IPCLN pada Rumah Sakit di Kota Banda Aceh dan Kab. Aceh Besar dengan nilai OR: 7,858 yang berarti bahwa kebutuhan untuk berprestasi berhubungan dengan kinerja perawat IPCLN sebanyak 7,858 kali atau 8 kali. Semakin tinggi motivasi perawat kebutuhan untuk berprestasi, maka semakin tinggi kinerja perawat IPCLN pada Rumah Sakit di Kota Banda Aceh dan Kab. Aceh Besar.

\section{PEMBAHASAN}

Hasil penelitian menunjukkan bahwa ada hubungan yang signifikan antara motivasi perawat dengan kinerja perawat IPCLN pada Rumah Sakit di Kota Banda Aceh dan Kab. Aceh Besar. Hal ini sejalan dengan pendapat yang dikemukakan oleh Buchanan \& Huczynski (2020) yaitu motivasi dalam bekerja merupakan salah satu 
variabel yang sangat menentukan kinerja seseorang. Motivasi merupakan kekuatan yang menyebabkan orang berperilaku secara positif dan kolektif dengan kemampuan menghasilkan kinerja. Motivasi juga merupakan kekuatan internal atau jenis energi dan mendorong kinerja. Lebih lanjut, penelitian Asmara et al., (2019) juga menunjukkan hasil yang senada yaitu terdapat hubungan yang signifikan antara motivasi dan kinerja IPCLN.

Beberapa penelitian terdahulu mengemukakan bahwa terdapat hubungan antara karakteristik responden dengan motivasi perawat. Baljoon et al., (2018) dalam kajiannya menunjukkan bahwa motivasi kerja perawat dipengaruhi oleh usia, pengalaman, otonomi, tingkat pendidikan dan jabatan administrasi. Perawat yang berumur lebih tua tampaknya memberikan nilai tambah pada aktualisasi diri yang dicapai, otonomi dan pengarahan diri sendiri. Hal ini disebabkan karena mereka mengenyam pendidikan lebih tinggi, pengalaman lebih banyak, dan masa kerja lebih lama. Mereka juga mengembangkan lebih percaya diri dan berpengalaman yang terbukti meningkatkan motivasi perawat. Kajian tersebut sejalan dengan hasil penelitian ini dimana karakteristik responden menjadi salah satu faktor pendukung kinerja perawat IPCLN.

Hasil penelitian ini juga sejalan kajian Gunawan et al., (2019) yang menyatakan variabel motivasi memiliki hubungan yang signifikan terhadap kinerja perawat ( $\mathrm{p}$ value $=0,004)$. Johnson et al., (2018) menyatakan kebutuhan untuk berprestasi adalah keinginan untuk menyelesaikan sesuatu yang sulit, menguasai tugas-tugas kompleks, mencapai standar kesuksesan yang tinggi dan melampaui yang lain. Oleh karena itu, individu yang mencari kebutuhan pencapaian akan dikenal sebagai orang yang mau menantang tujuan dan realistis. Individu yang bersedia mengambil risiko untuk mencapai tujuan mungkin gagal dalam situasi apa pun, tetapi komitmen dan konsentrasi pada hal itu akan menjadi kepuasan bagi mereka (Buchanan \& Hucynzki, 2019). Alhasan \& Arriff (2019) dalam kajiannya juga menyatakan hal senada bahwa motivasi berpengaruh positif dan sangat signifikan terhadap prestasi kerja. Oleh karena itu, dapat dipastikan bahwa motivasi dapat menarik keberhasilan dan prestasi kerja perawat di rumah sakit. Hasil dari kedua penelitian tersebut memiliki kesamaan dengan penelitian ini dimana sebahagian besar responden berjenis kelamin perempuan (dalam penelitian ini 95,3\% responden adalah perempuan) dan berhubungan dengan kinerja yang baik.

Pada sisi yang berbeda, hasil penelitian ini berseberangan dengan kajian Jooste \& Hamani (2017) yaitu menyatakan bahwa kebutuhan akan kekuasaan memiliki hubungan yang signifikan dengan kinerja perawat di rumah sakit. Sedangkan hasil kajian ini menunjukkan tidak adanya hubungan kebutuhan akan kekuasaan dengan kinerja perawat. Namun hal ini dapat dipahami karena terdapat perbedaan karakteristik responden dari sisi usia dengan penelitian ini. Hasil penelitian lain yang juga berbeda dengan hasil kajian ini ditunjukkan oleh Asmara et al., (2019) yang menyatakan bahwa supervisi tidak berhubungan dengan kinerja perawat IPCLN. Perbedaan tersebut juga dapat dipahami karena adanya perbedaan signifikan pada karakteristik responden penelitian yaitu masa kerja responden dengan selisih 2 tahun.

Hasil penelitian ini juga memberikan kesimpulan bahwa kebutuhan untuk berprestasi merupakan prediktor yang paling dominan berhubungan dengan kinerja perawat IPCLN pada Rumah Sakit di Kota Banda Aceh dan Kab. Aceh Besar (OR: 7,858). Kebutuhan untuk berprestasi berhubungan dengan kinerja perawat IPCLN sebanyak 7,858 kali atau 8 kali. Semakin tinggi motivasi perawat kebutuhan untuk 
berprestasi, maka semakin tinggi kinerja perawat IPCLN pada Rumah Sakit di Kota Banda Aceh dan Kab. Aceh Besar.

Lebih lanjut, hasil penelitian ini menunjukkan bahwa reward merupakan faktor yang paling berhubungan dengan kinerja IPCN. Odds Ratio (OR) variabel reward adalah 27.5 yang berarti reward yang baik memiliki peluang 27.5 baik untuk meningkatkan kinerja dibandingkan dengan IPCN yang menerima reward lebih sedikit setelah mengontrol variabel lain. Motivasi dari aspek kebutuhan untuk berprestasi menjadi faktor yang paling dominan berhubungan dengan kinerja IPCLN dalam penelitian ini disebabkan oleh responden yang berusia produktif ( $36-45$ tahun). Hal ini sejalan dengan kajian Manogaran \& Muthuveloo (2019) yang menyatakan bahwa usia perawat dalam kisaran 36 - 45 tahun cenderung memiliki kinerja yang baik. Hal ini disebabkan perawat berkeinginan untuk meningkatkan karier dengan menunjukkan prestasi kerja yang baik. Faktor ini menjadi dominan yang memotivasi perawat untuk menampilkan performa kerja yang baik dalam merawat pasien.

Motivasi dari aspek kebutuhan berprestasi pada perawat IPCLN dalam penelitian ini juga dapat berhubungan dengan tingkat pendidikan yang tinggi, masa kerja yang lebih lama dan jabatan sebagai PNS. Hal ini seperti yang dikemukakan oleh Baljoon et al., (2018) yaitu motivasi kerja perawat dipengaruhi oleh beberapa faktor pribadi dan organisasi. Usia perawat, tahun pengalaman, otonomi, tingkat pendidikan dan jabatan administrasi ditemukan sebagai karakteristik pribadi yang mempengaruhi tingkat motivasi perawat untuk berprestasi. Selain itu, pemberdayaan perawat, keterlibatan kerja, gaji dan tunjangan keuangan, pengawasan, promosi, imbalan, hubungan suportif (rekan kerja), komunikasi dan sifat pekerjaan diidentifikasi sebagai faktor organisasi yang mempengaruhi motivasi perawat untuk berprestasi.

\section{SIMPULAN}

Motivasi dan supervisi memiliki hubungan yang signifikan dengan kinerja perawat IPCLN, dan kebutuhan untuk berprestasi merupakan prediktor yang paling dominan berhubungan dengan kinerja perawat IPCLN pada Rumah Sakit di Kota Banda Aceh dan Kab. Aceh Besar. Semakin tinggi motivasi perawat untuk berprestasi, maka semakin tinggi kinerja perawat IPCLN Rumah Sakit di Kota Banda Aceh dan Kab. Aceh Besar.

\section{SARAN}

Kepada pihak manajemen pada Rumah Sakit di Kota Banda Aceh dan Kab Aceh Besar diharapkan dapat memberikan dukungan penuh kepada perawat IPCLN untuk melaksanakan pencegahan dan pengendalian infeksi di rumah sakit melalui kegiatan pelatihan, memberikan reward, dan menciptakan suasana kerja yang mendukung lahirnya motivasi untuk berprestasi pada perawat IPCLN.

\section{DAFTAR PUSTAKA}

Al-hasan, S. M. I., \& Arriff, T. M. (2019). The Effects of Motivation on Job Performance of Nurses in Jordanian Nursing Hospitals Shrouq. International Journal of Engineering Research And Management (IJERM), 6(05), 261-271. https://doi.org/10.1007/978-3-642-70967-8_18

Andersen, B. M. (2019). Hospital Infections: Surveillance. In Prevention and Control of Infections in Hospitals (pp. 13-22). Springer International Publishing. https://doi.org/10.1007/978-3-319-99921-0_2 
Asmara, A., Hariyati, R. T. S., Handiyani, H., \& Avia, I. (2019). Analysis of Infection Prevention Control Nurse Performance: A Descriptive Study. Enfermería Clínica, 29, 36-40. https://doi.org/10.1016/j.enfcli.2019.04.006

Baljoon, R., Banjar, H., \& Banakhar, M. (2018). Nurses' Work Motivation and the Factors Affecting It: A Scoping Review. International Journal of Nursing \& Clinical Practices, 5(1). https://doi.org/10.15344/2394-4978/2018/277

Buchanan, D. A., \& Huczynski, A. A. (2019). Organizational Behavior (10th ed.). https://www.pearson.com/uk/educators/higher-education-educators/ program/ Organizational-Behaviour-Buchanan-Huczynski-10th-Edition/ PGM2705518.html

Fitriyah, E. T., Dwidiyanti, M., \& Dwiantoro, L. (2018). Roles of Infection Prevention and Control Nurses (IPCNs) in Preparing for Emerging Infectious Diseases. Holistic Nursing and Health Science, 1(1), 46. https://doi.org/10.14710/hnhs.1.1.2018.46-54

Gunawan, N. P. I. N., Hariyati, R. T. S., \& Gayatri, D. (2019). Motivation as a Factor Affecting Nurse Performance in Regional General Hospitals: A Factors Analysis. Enfermería Clínica, 29, 515-520. https://doi.org/10.1016/j.enfcli.2019.04.078

Hutahaean, S., \& Handiyani, H. (2018). Pengembangan Fungsi dan Peran Kepala Ruangan Dalam Pencegahan dan Pengendalian Infeksi di Rumah Sakit X. Jurnal Akademi Keperawatan Husada Karya Jaya, 4(1), 53-64. http://ejurnal.husadakaryajaya.ac.id/index.php/JAKHKJ/article/view/73

Johnson, J., Irizarry, M., Nguyen, N., \& Maloney, P. (2018). Part 1: Foundational Theories of Human Motivation. University of Central Florida. https://www.semanticscholar.org/paper/Part-1\%3A-Foundational-Theories

Jooste, K., \& Hamani, M. (2017). The Motivational Needs of Primary Health Care Nurses to Acquire Power as Leaders in a Mine Clinic Setting. Health SA Gesondheid, 22, 43-51. https://doi.org/10.1016/j.hsag.2016.09.005

Kasumayanti, E. (2017). Faktor-Faktor yang Berhubungan dengan Infeksi Nosokomial pada Pengelola Limbah Medis Padat (Cleaning Service) di RSUD Bangkinang Tahun 2016. Jurnal Ners, 1(2), 20-32. https://journal.universitaspahlawan.ac.id/index.php/ners/article/view/114/83

Manogaran, P., \& Muthuveloo, R. (2019). The Antecedents of Job Performance Among Nurses Working in Malaysian Government Hospitals, Age Being A Moderator. The Malaysian Journal of Nursing, 11(01), 3-9. https://doi.org/10.31674/mjn.2019.v11i01.001

Marbun, N. C. P. (2020). Strategi Pencegahan dan Pengendalian dalam Upaya Pemutusan Rantai Infeksi di Rumah Sakit. 36. https://osf.io/preprints/a248z/

Niken, Y. (2020). Analisis Pelaksanaan Pencegahan dan Pengendalian Infeksi Nosokomial di Ruang ICU RSUD dr. Rasidin Padang Tahun 2020. Universitas Andalas. http://scholar.unand.ac.id/58493/

PPI. (2019). Laporan Infeksi Nosokomial

Romadhoni, S., \& Widowati, E. (2017). Penerapan Kewaspadaan Standar sebagai Upaya Pencegahan Bahaya Biologi pada Tenaga Keperawatan. HIGEIA (Journal of Public Health Research and Development), 1(4), 14-24. https://journal.unnes.ac.id/sju/index.php/higeia/article/view/15406

Salem, O. A. (2019). Knowledge and Practices of Nurses in Infection Prevention and Control within a Tertiary Care Hospital. Annals of Medical and Health Sciences Research, 9(1), 422-425. https://www.amhsr.org/articles/knowledge-andpractices-of-nurses-in-infection-prevention-and-a-tertiary-care-hospital.pdf 
Sapardi, V. S., Machmud, R., \& Gusty, R. P. (2018). Analisis Pelaksanaan Manajemen Pencegahan dan Pengendalian Healthcare Associated Infections di RSI Ibnusina. Jurnal Endurance, 3(2), 358. https://doi.org/10.22216/jen.v3i2.3029

Siahaan, M., Handiyani, H., \& Nurdiana, N. (2019). Optimization of the Roles and Responsibilities of Infection Prevention and Control Nurse in Hospital. International Journal of Nursing and Health Services (IJNHS), 2(4), 292-307. https://doi.org/10.35654/ijnhs.v2i4.116

Storr, J., Twyman, A., Zingg, W., Damani, N., Kilpatrick, C., Reilly, J., Price, L., Egger, M., Grayson, M. L., Kelley, E., \& Allegranzi, B. (2017). Core Components for Effective Infection Prevention and Control Programmes: New WHO EvidenceBased Recommendations. Antimicrobial Resistance \& Infection Control, 6(1), 6. https://doi.org/10.1186/s13756-016-0149-9

Suwito, S., Harun, C. Z., \& Ibrahim, S. (2017). Manajemen Pembelajaran Bahasa Inggris dalam Meningkatkan Prestasi Belajar Siswa pada SMP Negeri 1 Tapaktuan Aceh Selatan. Jurnal Administrasi Pendidikan: Program Pascasarjana Unsyiah, 5(2), 134-140. http://jurnal.unsyiah.ac.id/JAP/article/view/8363

Voidazan, S., Albu, S., Toth, R., Grigorescu, B., Rachita, A., \& Moldovan, I. (2020). Healthcare Associated Infections-A New Pathology in Medical Practice? International Journal of Environmental Research and Public Health, 17(3). https://doi.org/10.3390/ijerph17030760

WHO. (2016). Guidelines on Core Components of Infection Prevention and Control Programmes at the National and Acute Health Care Facility Level. In World Health Organization. http://apps.who.int/bookorders 